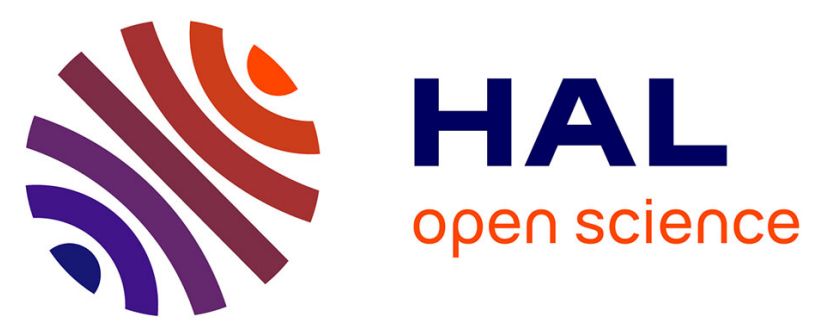

\title{
Atmospheric lead and heavy metal pollution records from a Belgian peat bog spanning the last two millenia: Human impact on a regional to global scale
}

François de Vleeschouwer, Laëtitia Gérard, Catherine Goormaghtigh, Nadine Mattielli, Gaël Le Roux, Nathalie Fagel

\section{To cite this version:}

François de Vleeschouwer, Laëtitia Gérard, Catherine Goormaghtigh, Nadine Mattielli, Gaël Le Roux, et al.. Atmospheric lead and heavy metal pollution records from a Belgian peat bog spanning the last two millenia: Human impact on a regional to global scale. Science of the Total Environment, 2007, vol. 377, pp.282-295. 10.1016/j.scitotenv.2007.02.017 . hal-00987398

\section{HAL Id: hal-00987398 https://hal.science/hal-00987398}

Submitted on 6 May 2014

HAL is a multi-disciplinary open access archive for the deposit and dissemination of scientific research documents, whether they are published or not. The documents may come from teaching and research institutions in France or abroad, or from public or private research centers.
L'archive ouverte pluridisciplinaire HAL, est destinée au dépôt et à la diffusion de documents scientifiques de niveau recherche, publiés ou non, émanant des établissements d'enseignement et de recherche français ou étrangers, des laboratoires publics ou privés. 


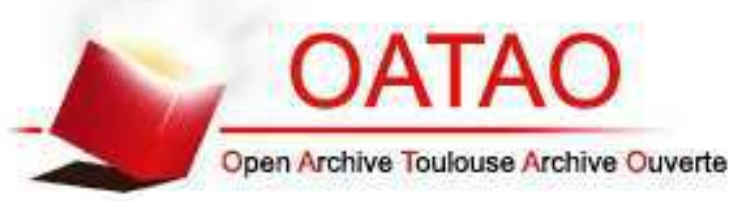

\section{Open Archive TOULOUSE Archive Ouverte (OATAO)}

OATAO is an open access repository that collects the work of Toulouse researchers and makes it freely available over the web where possible.

This is an author-deposited version published in : http://oatao.univ-toulouse.fr/ Eprints ID : 11495

To link to this article : doi:10.1016/j.scitotenv.2007.02.017

URL : http://dx.doi.org/10.1016/j.scitotenv.2007.02.017

To cite this version : De Vleeschouwer, François and Gérard, Laëtitia and Goormaghtigh, Catherine and Mattielli, Nadine and Le Roux, Gaël and Fagel, Nathalie Atmospheric lead and heavy metal pollution records from a Belgian peat bog spanning the last two millenia: Human impact on a regional to global scale. (2007) Science of the Total Environment, vol. 377 ( $\left.\mathrm{n}^{\circ} 2-3\right)$. pp. 282-295. ISSN 0048-9697

Any correspondance concerning this service should be sent to the repository administrator: staff-oatao@ listes-diff.inp-toulouse.fr 


\title{
Atmospheric lead and heavy metal pollution records from a Belgian peat bog spanning the last two millenia: Human impact on a regional to global scale
}

\author{
François De Vleeschouwer ${ }^{\mathrm{a}, *}$, Laëtitia Gérard ${ }^{\mathrm{a}}$, Catherine Goormaghtigh ${ }^{\mathrm{b}}$, \\ Nadine Mattielli ${ }^{\mathrm{b}}$, Gaël Le Roux ${ }^{\mathrm{c}, 1}$, Nathalie Fagel ${ }^{\mathrm{a}}$ \\ ${ }^{a}$ URAP, Département de Géologie, Université de Liège, Allée du 6 Août B18 Sart Tilman B4000 - Liège Belgium \\ ${ }^{\mathrm{b}}$ Unité de recherche: "Isotopes, Pétrologie et Environnement", Département des Sciences de la Terre et de l'Environnement, \\ CP 160/02 Université Libre de Bruxelles, Avenue FD. Roosevelt, 50, B-1050 Bruxelles, Belgium \\ ${ }^{\mathrm{c}}$ Institute of Environmental Geochemistry, University of Heidelberg, Im Neuenheimer Feld 236 B-69120 Heidelberg, Germany
}

\begin{abstract}
Europe has been continuously polluted throughout the last two millennia. During the Roman Empire, these pollutions were mainly from ore extraction and smelting across Europe. Then, during the Middle Ages and the Early times of Industrial revolution (i.e. 1750), these pollutions extended to coal burning and combustion engine. Belgian ombrotrophic peat bogs have proved an effective archive of these pollutants and provide the opportunity to reconstruct the history of atmospheric deposition in NW Europe.

The results of recent and past trace metal accumulation and $\mathrm{Pb}$ isotopes from a one-meter peat core (in the Misten peat bog) have been derived using XRF and Nu-plasma MC-ICP-MS. Combined with ${ }^{14} \mathrm{C}$ and ${ }^{210} \mathrm{~Pb}$ dates these data have enabled us to trace fluxes in anthropogenic pollution back to original Roman times.

Several periods of well-known $\mathrm{Pb}$ pollution events are clearly recorded including the Early and Late Roman Empire, the Middle Ages and the second industrial revolution. Also recorded is the introduction of leaded gasoline, and more recently the introduction of unleaded gasoline. Lead isotopes in this site have also enabled us to fingerprint several regional and global sources of anthropogenic particles.
\end{abstract}

Keywords: Peat; Geochemistry; Belgium; Pollution; Last two millennia

* Corresponding author. Unité de Recherche Argiles et Paléoclimats, Département de Géologie, Université de Liège, Allée du 6 Août B18 Sart Tilman B4000 - Liège Belgium. Tel.: +324366 22 10; fax: +32 4 3662202 .

E-mail address: fdevleeschouwer@student.ulg.ac.be (F. De Vleeschouwer).

${ }^{1}$ Now at :Institut de Radioprotection et Sûreté Nucléaire, DEI/ LERCM CEN Cadarache Bât. 153, BP 3, 3115 St Paul lez Durance, France.

\section{Introduction}

Centuries of atmospheric pollution caused by industrial activities, coal burning, and petroleum use has left an indelible mark in Europe's soils in the form of heavy metals. The fallout of these anthropogenic aerosols mix with natural aerosols, for example from rock weathering become incorporated into the soils 

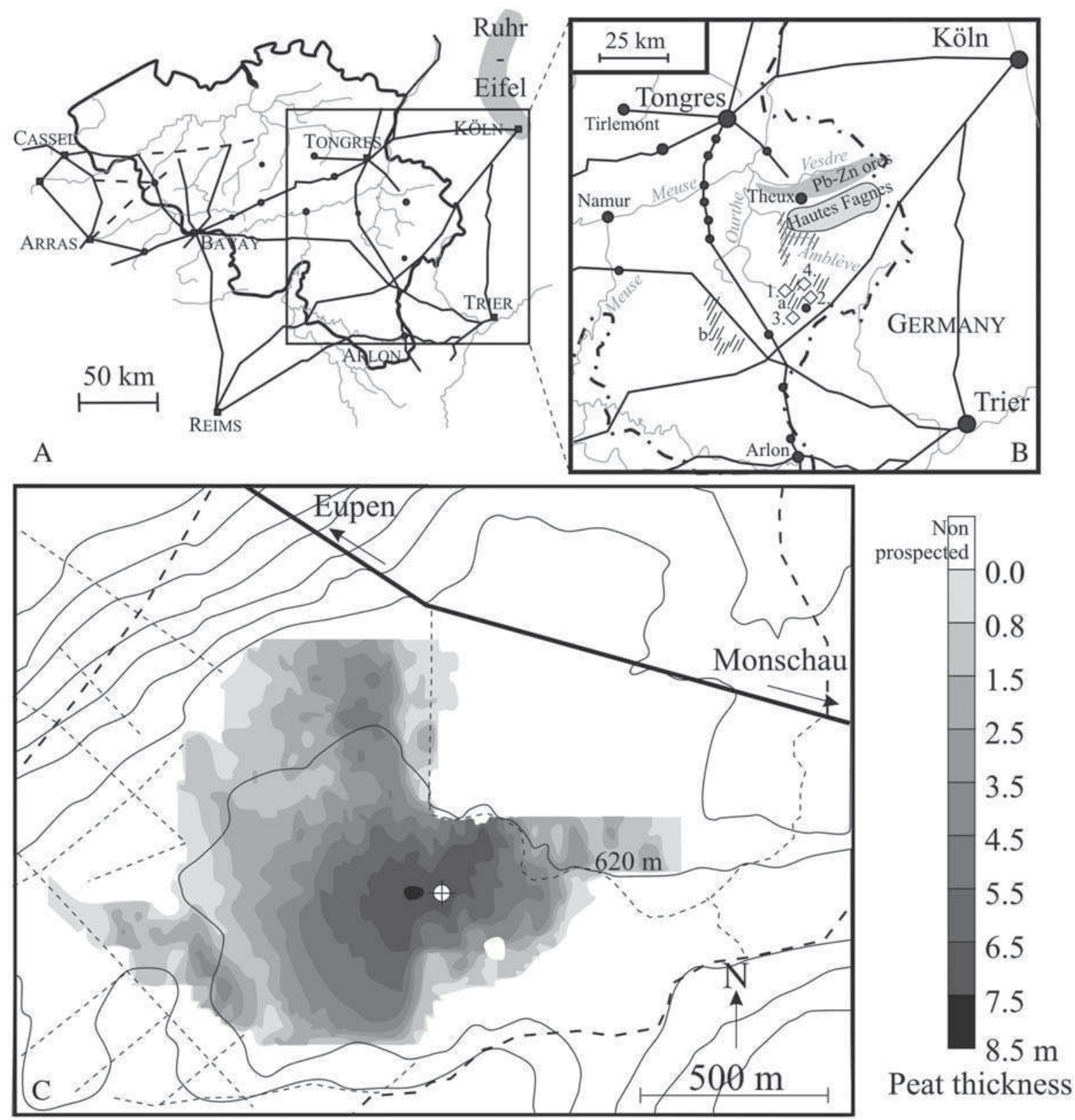

Fig. 1. A. General map showing the Roman road system (redrawn after Corbiau, 1998). The actual Ruhr-Eifel Region is also reported. Plain lines: Roman road system. Black circles: principal Roman cities and village (size of the circles gives an idea of the relative importance of each city). Grey lines: river system. B. Location map of the Hautes Fagnes Plateau and its surroundings. Dashed area: alluvial mounds remaining from gold prospecting, ${ }^{14}$ C-dated at A: 120 B.C. -140 A.D. and B: 400 B.C. -200 B.C. Diamonds: 1 . the gold mine gallery with dated wooden piece; 2 . the open-air gold mine (undated); 3. sites with roman graves; 4. site with Roman coins. Plain lines: Roman road system. Black circles: principal roman cities and village (size of the circles gives an idea of the relative importance of each city). Grey lines: river system. Pb-Zn ores: lead-zinc ore deposit (after Dejonghe, 1998). C. Radar derived peat thickness of the Misten bog (modified after Wastiaux and Schumacker, 2003). Altitude lines are 5 m distant in altitude. The different dotted lines are forestry ways. Coring location is reported by the open circle.

where they are preserved. Over time the release of these heavy metals including lead, zinc, copper, and nickel, which well exceed natural levels (Boyd, 2004), can contaminate the soil and surrounding land.
Peat bogs are particularly sensitive archives of human activities and more specifically of atmospheric pollution (e.g. Shotyk et al., 1996, 2003; Weiss et al., 2002; Martinez-Cortizas et al., 2002; West et al., 1997; 
Mighall et al., 2002; Novak et al., 2003; Le Roux et al., 2004). Most importantly, peat is particularly effective at preserving atmospheric metal deposition in the form of lead (e.g. Shotyk, 2002; Shotyk et al., 1998, 2003; Vile et al., 1999; Weiss et al., 1999), copper (Rausch et al., 2005; Mighall et al., 2002), nickel (Krachler et al., 2003) and zinc (Rausch et al., 2005; Twardowska et al., 1999). Recent research has shown that ancient $\mathrm{Pb}$ contamination in peat can be traced by $\mathrm{Pb}$ isotopes and fingerprinted to a local or regional origin (e.g. Kempter and Frenzel, 1999; Monna et al., 2000; Le Roux et al., 2004; Kylander et al., 2005). The more recent atmospheric $\mathrm{Pb}$ pollution (i.e. coal burning and leaded gasoline) is shown to be more regional or even continental (Dunlap et al., 1999; Véron et al., 1999; Le Roux et al., 2005; Shotyk et al., 2005).

The Hautes Fagnes Plateau (SE Belgium), the largest peatland area in Belgium, is located in an intermediate position in Western Europe (surrounded by France, U.K. and Germany). The Hautes Fagnes Plateau is also situated to the South of $\mathrm{Pb}-\mathrm{Zn}$ ore deposits (extracted between the 19th and 20th centuries; Dejonghe, 1998) and nearby the German border which is $300 \mathrm{~km}$ from the Region of the Ruhr-Eifel industrial area. In more ancient times the Hautes Fagnes plateau was surrounded by several Roman sites. On the site several archaeological (Cauuet, 2005; Renson et al., 2005, 2007; Remy, 1981) and historical (Graillet, 1998) investigations support Roman occupation and ore mining in the area (see Sections 4.1 and 4.2).

In this paper, we present the elemental records of $\mathrm{Si}$, $\mathrm{Ti}, \mathrm{Sr}, \mathrm{Pb}, \mathrm{Cu}, \mathrm{Zn}$ and $\mathrm{Ni}$ for the top meter of a peat core from the Misten Bog from the Hautes Fagnes Plateau. Si and $\mathrm{Ti}$ were used as evidence for periods of enhanced atmospheric particle and $\mathrm{Sr}$ is used to demonstrate the ombrotrophic character of the bog. Ti is also used as a reference element for the calculation of enrichment factors. $\mathrm{A} \mathrm{Pb}$ isotopic study is also presented in order to decipher from the possible lead pollution sources. The main aim of this study was to use the results of a high resolution investigation of heavy metal pollution in a peat core from Misten Bog to reconstruct the pollution history of the Hautes Fagnes and in turn, contribute to the pollution history of Europe.

\section{Material and methods}

\subsection{Site description}

The Misten bog is located in the Northern part of the Hautes Fagnes Plateau, $5 \mathrm{~km}$ from the German border (Fig. 1A). It is a law-protected raised bog accumulating more than $8 \mathrm{~m}$ of peat (Wastiaux and Schumacker,
2003), dating back to 9000 years ago (Persh, 1950; Gérard, 2004). The first meter of the Misten bog is composed of young Sphagnum imbricatum peat with Eriophorum fragments. Between 30 and $20 \mathrm{~cm}$, sphagnum species also include aquatic species like Sphagnum cuspidata (Persh, 1950).

\subsection{Sampling and sample preparation}

In summer 2003, a $1 \mathrm{~m}$ long, $10 \mathrm{~cm}$ diameter core was retrieved using a Belorussian-type stainless steel Dcorer (Belokopytov and Beresnevich, 1955; Jowsey, 1965). The inner parts of the corer are coated with Teflon ${ }^{\circledR}$ adhesive to avoid metal contamination by the coring device. Cores were bagged into PVC tubes and wrapped in plastic. The $1 \mathrm{~m}$ core was cut into $1 \mathrm{~cm}$ slices in the laboratory using clean plastic tools. Each sample was dried $\left(105^{\circ} \mathrm{C}, 12 \mathrm{~h}\right)$ and then ground twice: (1) manually using an agate mortar; (2) mechanically in agate jars pulverisette (400 rpm for $1 \mathrm{~h}$ ). The mortar and jars were cleaned between each samples using tap and then $\mathrm{mQ}$ water, and finally air-dried.

\subsection{XRF analyses}

An average of $3.5 \mathrm{~g}$ of peat powder was pressed into pellets at $200 \mathrm{kN} / \mathrm{cm}^{2}$. Pellets were analyzed using ARL 9400 XP XRF spectrometer (University of Liège) for the following elements: $\mathrm{Si}, \mathrm{Ti}, \mathrm{Sr}, \mathrm{Ni}, \mathrm{Zn}, \mathrm{Cu}$ and $\mathrm{Pb}$. Calibrations were made using international standards: coals (CLB-1, NIST 1632b et NIST 1635), lichen (BCR-482), pond sediments (NIES-2), tea leaves (NIES-7), vehicle exhaust particulates (NIES-8) and sediments (JSD-2, JSD3, SGR). Reproducibility, accuracy and detection limits are summarized in Table 1. Sediments and vehicle exhaust particle standards were used in order to extend the concentration range to higher values often occurring in highly polluted recent peat

Table 1

Mean statistics calculated on the analyzed standards (see text)

\begin{tabular}{llllllll}
\hline & $\mathrm{Si}$ & $\mathrm{Ti}$ & $\mathrm{Sr}$ & $\mathrm{Cu}$ & $\mathrm{Pb}$ & $\mathrm{Ni}$ & $\mathrm{Zn}$ \\
\hline Mean DL & 0.18 & 70 & 3.7 & 1.5 & 3.2 & 1.3 & 1.4 \\
Mean QL & 0.55 & 210 & 11.1 & 4.6 & 9.7 & 3.8 & 4.2 \\
Mean error & 0.5 & 4.7 & 4.6 & 5.2 & 6.5 & 20.5 & 14.7 \\
Mean & 97 & 96 & 98 & 75 & 87 & 93 & 96 \\
reproducibility & & & & & & & \\
\hline
\end{tabular}

Mean DL: mean detection limit (i.e. $3 \sigma$ ); Mean QL: mean quantification limit (i.e. $9 \sigma$ ). Both are in $\%$ for $\mathrm{Si}$ and in ppm for other elements, respectively. Mean error $(\%, n=10)=100 \times[$ mean standard values certified or suggested values]/certified or suggested values. Mean reproducibility $(\%, n=10)=100 \times[$ mean standard values - standard deviation]/mean standard values. 
layers. Measured sample concentrations are presented in Table 2.

\subsection{Measurement of heavy metals in deep peat samples}

Two samples from the bottom of the bog (660 and $678 \mathrm{~cm}$ depth, Table 2) were analyzed to establish natural background concentrations. As their elemental content could be expected to be very low and thus under XRF detection limits, these two samples were acid digested in clean air cabinets (University of Liège). Acid digestions consisted of a two-step dissolution in closed Savilex ${ }^{\circledR}$ beakers: (1) addition of $\mathrm{H}_{2} \mathrm{O}_{2} 30 \%$ p.a. and $\mathrm{HNO}_{3} 65 \%$ cc. sub. in a proportion of $3: 1$ for organic matrix dissolution, and (2) addition of HF suprapur (Merck) $+\mathrm{HNO}_{3} 65 \%$ cc. sub. of 1:6 for mineral matrix dissolution. The beakers were placed on a hot plate at $130{ }^{\circ} \mathrm{C}$ for 4 days. After drying, $0.5 \mathrm{~N} \mathrm{HNO} \mathrm{cc.} \mathrm{sub.} \mathrm{was}$ added to obtain the solution. Analyses were performed on ICP-AES (IRIS Advantage) at the MRAC-Tervuren (Belgium). Calibrations were made with $\mathrm{In}-\mathrm{Ru}-\mathrm{Re}-\mathrm{Bi}$ internal standards (10 and $20 \mathrm{ppb}$ ) and two international reference materials: CRM-100 beech leaves (EU certificated) and granite GA (Govindaraju and de la Roche, 1977). Accuracy was between $1-11 \%$ for major elements and $1-2 \%$ for trace metals. Detection limits were lower than $1 \mathrm{ppm}$ for major elements. Detection limits for trace metals and other trace elements were lower than 1 and $10 \mathrm{ppb}$, respectively.

\subsection{Acid digestion for lead isotope analyses}

All the samples were processed in clean air cabinets (University of Liège and University of Brussels, Belgium). $50 \mathrm{mg}$ of original dry powder was aciddigested as previously described at Section 2.4, to which was added a further step. After drying, $6 \mathrm{~N} \mathrm{HCl}$ was added and the perfectly pure solution obtained was slowly evaporated. The dried residues were dissolved in $\mathrm{HBr} 6 \% \mathrm{cc}$. sub. prior to the chromatographic separation.

Lead chemistry was performed by a single passage through anionic exchange micro-columns following the protocol of Weis et al. (2005). Distilled $\left(\mathrm{HNO}_{3}\right)$ or subboiled $(\mathrm{HCl}, \mathrm{HBr})$ acids were used during the chemical treatment. Total procedural $\mathrm{Pb}$ blanks ranged from $0.1 \mathrm{ng}$ to $0.4 \mathrm{ng}$ and were negligible regarding $\mathrm{Pb}$ contents in $50 \mathrm{mg}$ of sample $(615 \mathrm{ng}$ at $28.5 \mathrm{~cm}<$ Misten content $<4745 \mathrm{ng}$ at $3.5 \mathrm{~cm}$ ).

Lead isotopic ratios were measured on a $\mathrm{Nu}$ Instruments Multi-Collector Inductively Coupled Plasma Mass Spectrometer (MC-ICP-MS) at University of Brussels during four analysis sessions of 5 days in total.
Table 2

Elemental content along the top meter of a peat core from the Misten Bog

\begin{tabular}{|c|c|c|c|c|c|c|c|c|}
\hline Depth & $\mathrm{Si}$ & $\mathrm{Ti}$ & $\mathrm{Sr}$ & $\mathrm{Cu}$ & $\mathrm{Ni}$ & $\mathrm{Pb}$ & $\mathrm{Zn}$ & Pb E.F. \\
\hline 0.5 & 4.32 & 1187 & 14.1 & 8.40 & 14.2 & 537 & 106 & 109 \\
\hline 1.5 & 4.34 & 1206 & 17.2 & 12.3 & 18.3 & 647 & 133 & 130 \\
\hline 2.5 & 3.41 & 1223 & 16.4 & 13.2 & 14.5 & 766 & 153 & 151 \\
\hline 3.5 & 3.40 & 1048 & 19.1 & 18.7 & 22.8 & 949 & 214 & 218 \\
\hline 4.5 & 3.67 & 1056 & 16.1 & 10.6 & 9.4 & 617 & 133 & 141 \\
\hline 5.5 & 4,93 & 1066 & 16.7 & 8.71 & 7.2 & 413 & 117 & 93 \\
\hline 6.5 & 3,60 & 785 & 14.5 & 5.60 & 3.9 & 299 & 106 & 92 \\
\hline 7.5 & 2,60 & 677 & 15.7 & 4.63 & 4.9 & 265 & 135 & 95 \\
\hline 8.5 & 1,98 & 585 & 13.6 & 2.70 & $<$ D.L. & 207 & 120 & 85 \\
\hline 9.5 & 1,97 & 576 & 12.7 & 2.08 & $<$ D.L. & 139 & 105 & 58 \\
\hline 10.5 & 1,48 & 549 & 10.4 & 1.80 & $<$ D.L. & 89.1 & 91.6 & 39 \\
\hline 12.5 & 1,53 & 592 & 12.6 & 1.80 & $<$ D.L. & 61.6 & 105 & 25 \\
\hline 14.5 & 0,58 & 272 & 10.5 & 1.70 & $<$ D.L. & 32.3 & 97.3 & 29 \\
\hline 16.5 & 0,53 & 232 & 13.5 & 2.40 & $<$ D.L. & 40.6 & 135 & 42 \\
\hline 18.5 & 0,61 & 259 & 10.2 & 2.70 & $<$ D.L. & 31.9 & 91.8 & 30 \\
\hline 20.5 & 0.44 & 174 & 12.9 & 2.50 & $<$ D.L. & 32.1 & 107 & 45 \\
\hline 22.5 & 0.31 & 153 & 17.0 & 2.20 & $<$ D.L. & 28.7 & 123 & 45 \\
\hline 24.5 & 0.46 & 200 & 15.3 & 2.20 & $<$ D.L. & 25.0 & 102 & 30 \\
\hline 26.5 & 0.42 & 191 & 12.9 & 2.00 & $<$ D.L. & 19.0 & 70.5 & 24 \\
\hline 28.5 & 0.66 & 302 & 10.3 & $<$ D.L. & $<$ D.L. & 12.3 & 47.1 & 10 \\
\hline 30.5 & 0.63 & 272 & 13.6 & 1.60 & $<$ D.L. & 13.5 & 52.1 & 12 \\
\hline 32.5 & 0.47 & 236 & 13.4 & 2.50 & $<$ D.L. & 22.4 & 50.6 & 23 \\
\hline 34.5 & 0.38 & 197 & 13.2 & 2.10 & $<$ D.L. & 20.7 & 42.8 & 25 \\
\hline 36.5 & 0.59 & 259 & 12.4 & 2.40 & $<$ D.L. & 21.3 & 34.2 & 20 \\
\hline 38.5 & 0.33 & 138 & 12.9 & 2.90 & $<$ D.L. & 24.9 & 33.8 & 44 \\
\hline 40.5 & 0.28 & 154 & 14.9 & 3.00 & 3.70 & 28.9 & 28.8 & 45 \\
\hline 42.5 & 0.33 & 165 & 15.6 & 2.50 & $<$ D.L. & 22.2 & 23.0 & 32 \\
\hline 44.5 & 0.37 & 159 & 16.8 & 2.00 & $<$ D.L. & 19.4 & 18.3 & 29 \\
\hline 46.5 & 0.39 & 145 & 18.0 & 3.90 & 4.00 & 35.0 & 17.7 & 58 \\
\hline 48.5 & 0.37 & 146 & 16.0 & 3.30 & 3.50 & 30.9 & 14.5 & 51 \\
\hline 49.5 & 0.41 & 159 & 18.1 & 4.47 & 6.69 & 39.5 & 16.7 & 60 \\
\hline 50.5 & 0.61 & 223 & 17.0 & 5.70 & 13.1 & 84.6 & 34.2 & 92 \\
\hline 51.5 & 0.41 & 154 & 16.4 & 6.08 & 10.9 & 58.6 & 16.7 & 92 \\
\hline 52.5 & 0.30 & 116 & 14.1 & 4.70 & 7.30 & 45.2 & 12.5 & 94 \\
\hline 54.5 & 0.32 & 136 & 13.4 & 4.10 & 6.40 & 43.2 & 9.20 & 76 \\
\hline 56.5 & 0.48 & 138 & 13.8 & 4.10 & 6.50 & 43.8 & 8.80 & 76 \\
\hline 58.5 & 0.63 & 195 & 12.9 & 4.40 & 7.80 & 47.4 & 8.60 & 59 \\
\hline 60.5 & 1.25 & 318 & 9.30 & $<$ D.L. & $<$ D.L. & 32.3 & $<$ D.L. & 25 \\
\hline 64.5 & 0.67 & 233 & 7.50 & $<$ D.L. & 6.43 & 57.9 & $<$ D.L. & 60 \\
\hline 68.5 & 0.79 & 228 & 6.99 & $<$ D.L. & 3.85 & 60.4 & $<$ D.L. & 64 \\
\hline 72.5 & 1.54 & 468 & 7.91 & $<$ D.L. & 4.28 & 82.9 & $<$ D.L. & 43 \\
\hline 76.5 & 0.52 & 193 & 7.80 & $<$ D.L. & 4.25 & 81.8 & $<$ D.L. & 120 \\
\hline 80.5 & 0.70 & 252 & 10.6 & $<$ D.L. & $<$ D.L. & 139 & $<$ D.L. & 133 \\
\hline 86.5 & 0.65 & 254 & 6.97 & $<$ D.L. & $<$ D.L. & 95.1 & $<$ D.L. & 90 \\
\hline 88.5 & 1.07 & 335 & 6.96 & $<$ D.L. & 6.19 & 98.7 & $<$ D.L. & 71 \\
\hline 96.5 & 0.36 & 98 & 8.53 & 3.06 & 7.26 & 60.9 & $<$ D.L. & 150 \\
\hline 98.5 & 0.44 & 144 & 9.11 & 10.2 & 12.4 & 69.1 & $<$ D.L. & 116 \\
\hline 660 & - & 2081 & 28.3 & $<$ D.L. & 51.4 & 7.66 & 20.8 & 1 \\
\hline 678 & - & 4215 & 63.9 & 11.38 & 50.4 & 16.1 & 18.1 & 1 \\
\hline
\end{tabular}

$<$ D.L. : under detection limits. Values in italic are semi-quantitative $(3 \sigma<>6 \sigma)$. bis-samples are replicates. Si concentrations are not measured for 660 and $678 \mathrm{~cm}$ samples because of $\mathrm{SiF}_{4}$ volatilization during HF digestion. 
Table 3

${ }^{208} \mathrm{~Pb} /{ }^{204} \mathrm{~Pb},{ }^{207} \mathrm{~Pb} /{ }^{204} \mathrm{~Pb},{ }^{206} \mathrm{~Pb} /{ }^{204} \mathrm{~Pb},{ }^{207} \mathrm{~Pb} /{ }^{206} \mathrm{~Pb},{ }^{208} \mathrm{~Pb} /{ }^{207} \mathrm{~Pb},{ }^{208} \mathrm{~Pb} /{ }^{206} \mathrm{~Pb}$ isotopic ratios

\begin{tabular}{|c|c|c|c|c|c|c|c|c|c|c|}
\hline Depth & ${ }^{208} \mathrm{~Pb} /{ }^{204} \mathrm{~Pb}$ & $2 \mathrm{se}$ & ${ }^{207} \mathrm{~Pb} /{ }^{204} \mathrm{~Pb}$ & $2 \mathrm{se}$ & ${ }^{206} \mathrm{~Pb} /{ }^{204} \mathrm{~Pb}$ & $2 \mathrm{se}$ & ${ }^{208} \mathrm{~Pb} /{ }^{206} \mathrm{~Pb}$ & $2 \mathrm{se}$ & ${ }^{207} \mathrm{~Pb} /{ }^{206} \mathrm{~Pb}$ & $2 \mathrm{se}$ \\
\hline 0.5 & 37.9300 & 0.0030 & 15.5947 & 0.0011 & 17.9864 & 0.0012 & 2.1088 & 0.00180 & 0.8670 & 0.00010 \\
\hline 0.5 bis & 37.9300 & 0.0040 & 15.5947 & 0.0015 & 17.9856 & 0.0017 & 2.1089 & 0.0023 & 0.8671 & 0.00020 \\
\hline 2.5 & 37.9350 & 0.0020 & 15.5962 & 0.0008 & 17.9857 & 0.0009 & 2.1092 & 0.00110 & 0.8671 & 0.00010 \\
\hline 5.5 & 37.8979 & 0.0031 & 15.5829 & 0.0013 & 17.9701 & 0.0017 & 2.1089 & 0.00009 & 0.8672 & 0.00002 \\
\hline $5.5 \mathrm{bis}$ & 37.9221 & 0.0034 & 15.5931 & 0.0014 & 17.9806 & 0.0016 & 2.1090 & 0.0001 & 0.8672 & 0.00003 \\
\hline 8.5 & 37.9540 & 0.0020 & 15.5969 & 0.0007 & 18.0042 & 0.0009 & 2.1081 & 0.00110 & 0.8663 & 0.00020 \\
\hline 10.5 & 37.9465 & 0.0041 & 15.5867 & 0.0015 & 18.0102 & 0.0017 & 2.1069 & 0.00008 & 0.8655 & 0.00002 \\
\hline 15.5 & 38.1640 & 0.0030 & 15.6117 & 0.0011 & 18.2119 & 0.0014 & 2.0956 & 0.00160 & 0.8572 & 0.00030 \\
\hline 20.5 & 38.1903 & 0.0032 & 15.6087 & 0.0013 & 18.2464 & 0.0014 & 2.0930 & 0.00009 & 0.8554 & 0.00003 \\
\hline 24.5 & 38.1417 & 0.0038 & 15.6030 & 0.0013 & 18.1881 & 0.0016 & 2.0969 & 0.00007 & 0.8578 & 0.00001 \\
\hline 30.5 & 37.9950 & 0.0060 & 15.5971 & 0.0023 & 18.0678 & 0.0025 & 2.1029 & 0.00350 & 0.8633 & 0.00020 \\
\hline 40.5 & 38.1196 & 0.0027 & 15.6078 & 0.0011 & 18.1652 & 0.0015 & 2.0985 & 0.00011 & 0.8592 & 0.00004 \\
\hline 50.5 & 37.9310 & 0.0060 & 15.5935 & 0.0024 & 17.9881 & 0.0029 & 2.1087 & 0.00310 & 0.8669 & 0.00050 \\
\hline 50.5 bis & 37.9400 & 0.0040 & 15.5985 & 0.0014 & 17.9964 & 0.0016 & 2.1082 & 0.0024 & 0.8668 & 0.00020 \\
\hline 52.5 & 37.9844 & 0.0043 & 15.5943 & 0.0015 & 18.0424 & 0.0017 & 2.1052 & 0.00010 & 0.8643 & 0.00003 \\
\hline 52.5 bis & 37.9789 & 0.0079 & 15.5930 & 0.0030 & 18.0415 & 0.0022 & 2.1051 & 0.0001 & 0.8643 & 0.00003 \\
\hline 56.5 & 38.1012 & 0.0094 & 15.5985 & 0.0038 & 18.1486 & 0.0049 & 2.1319 & 0.00007 & 0.8594 & 0.00003 \\
\hline 88.5 & 38.3310 & 0.0040 & 15.6191 & 0.0015 & 18.3631 & 0.0020 & 2.0874 & 0.00200 & 0.8506 & 0.00050 \\
\hline 98.5 & 38.2245 & 0.0041 & 15.6088 & 0.0015 & 18.2656 & 0.0018 & 2.0926 & 0.00008 & 0.8545 & 0.00003 \\
\hline 660 & 39.0227 & 0.0065 & 15.6770 & 0.0056 & 19.0430 & 0.0029 & 2.0491 & 0.00006 & 0.8233 & 0.00002 \\
\hline 678 & 38.9966 & 0.0033 & 15.6878 & 0.0009 & 19.2016 & 0.0013 & 2.0309 & 0.00004 & 0.8170 & 0.00001 \\
\hline
\end{tabular}

se refers to standard error, i.e. derived from standard deviation.

Configuration of the collector array enabled simultaneous collection of $\mathrm{Pb}$ (for masses 208, 207, 206, 204) together with $\mathrm{Tl}(205,203)$ and $\mathrm{Hg}(202) . \mathrm{Hg}$ was used to correct interferences on mass 204 (because of ${ }^{204} \mathrm{Hg}$ ). $\mathrm{Tl}$ is added to all samples and standards to monitor and correct instrumental mass fractionation. All standard and sample solutions were prepared to obtain a $\mathrm{Pb} / \mathrm{Tl}$ ratio of $\sim 5$, a signal of $\sim 100 \mathrm{mV}$ on the axial collector $\left({ }^{204} \mathrm{~Pb}\right)$, and to match the $\mathrm{Pb}, \mathrm{Tl}$ concentrations of the standards (200 ppb and $50 \mathrm{ppb}$, respectively). The NBS981 provided regular checks of reproducibility and drift during each day. Sixty-four analyses of the NBS981 Pb standard were completed gave mean values of ${ }^{208} \mathrm{~Pb} /{ }^{204} \mathrm{~Pb}=36.7164 \pm 0.094$ (2SD), ${ }^{207} \mathrm{~Pb} /{ }^{204} \mathrm{~Pb}=$ $15.4969 \pm 0.0036,{ }^{206} \mathrm{~Pb} /{ }^{204} \mathrm{~Pb}=16.9401 \pm 0.0036$, which are in agreement with the long-term internal laboratory reproducibility $\left(n= \pm 1000,{ }^{208} \mathrm{~Pb} /{ }^{204} \mathrm{~Pb}=\right.$ $36.7130 \pm 0.012$ (2SD), ${ }^{207} \mathrm{~Pb} /{ }^{204} \mathrm{~Pb}=15.4950 \pm 0.004$, $\left.{ }^{206} \mathrm{~Pb} /{ }^{204} \mathrm{~Pb}=16.9393 \pm 0.0044\right)$, the TIMS triple spike values (Galer and Abouchami, 1998) and other $\mathrm{Nu}$ Plasma published values (Weis et al., 2005). Replicates (i.e., a re-run of the same sample solution) are presented in Table 3.

\section{6. ${ }^{14} \mathrm{C}$ and ${ }^{210} \mathrm{~Pb}$ dating}

A ${ }^{14} \mathrm{C}$ measurement was performed on a bulk peat sample at $53.5 \mathrm{~cm}$ depth using Accelerator Mass
Spectrometry (1.5 SDH-Pelletron Model "Compact Carbon AMS") at Poznan Radiocarbon Laboratory (Poland). This provided an age interval of $250 \mathrm{yr}$ A.D.401 yr A.D. (calibrated by Calib 5.0.2, Stuiver et al., 2005; Reimer et al., 2004) and a mean date of $326 \pm 76 \mathrm{yr}$ A.D. [uncalibrated age of $1715 \pm 30$ yr B.P., Poz-7012]. Radionuclides $\left({ }^{210} \mathrm{~Pb},{ }^{214} \mathrm{~Pb}\right)$ were measured using low background Gamma Spectrometry (GCW4028, HPGe, Canberra) in Heidelberg. The maximum depth at which unsupported ${ }^{210} \mathrm{~Pb}$ could be detected is $10 \mathrm{~cm}$. The agedepth relationship was calculated using the CRS model (Appleby, 2001). Errors on ${ }^{210} \mathrm{~Pb}$ age dating and peat accumulation rate were calculated by propagation of

\begin{tabular}{lccc}
$\begin{array}{l}\text { Table } 4 \\
{ }^{210} \mathrm{~Pb} \text { age depth relationship in the } 10.5 \mathrm{~cm} \text { depth sample }\end{array}$ \\
$\begin{array}{l}\text { Laboratory } \\
\text { no. }\end{array}$ & $\begin{array}{l}\text { Mean depth } \\
(\mathrm{cm})\end{array}$ & $\begin{array}{l}{ }^{210} \mathrm{~Pb} \text { corrected date } \\
\text { (year) }\end{array}$ & $\begin{array}{l}\text { Uncertainty } \\
\text { (year) }\end{array}$ \\
\hline 1 & 0.5 & 2003 & 0 \\
2 & 1.5 & 1984 & 2 \\
3 & 2.5 & 1964 & 5 \\
4 & 3.5 & 1950 & 8 \\
5 & 4.5 & 1938 & 10 \\
6 & 5.5 & 1935 & 10 \\
7 & 6.5 & 1920 & 16 \\
8 & 7.5 & 1874 & 44 \\
9 & 8.5 & 1835 & 28 \\
10 & 9.5 & 1835 & 28 \\
11 & 10.5 & 1813 & 57 \\
\hline
\end{tabular}


A
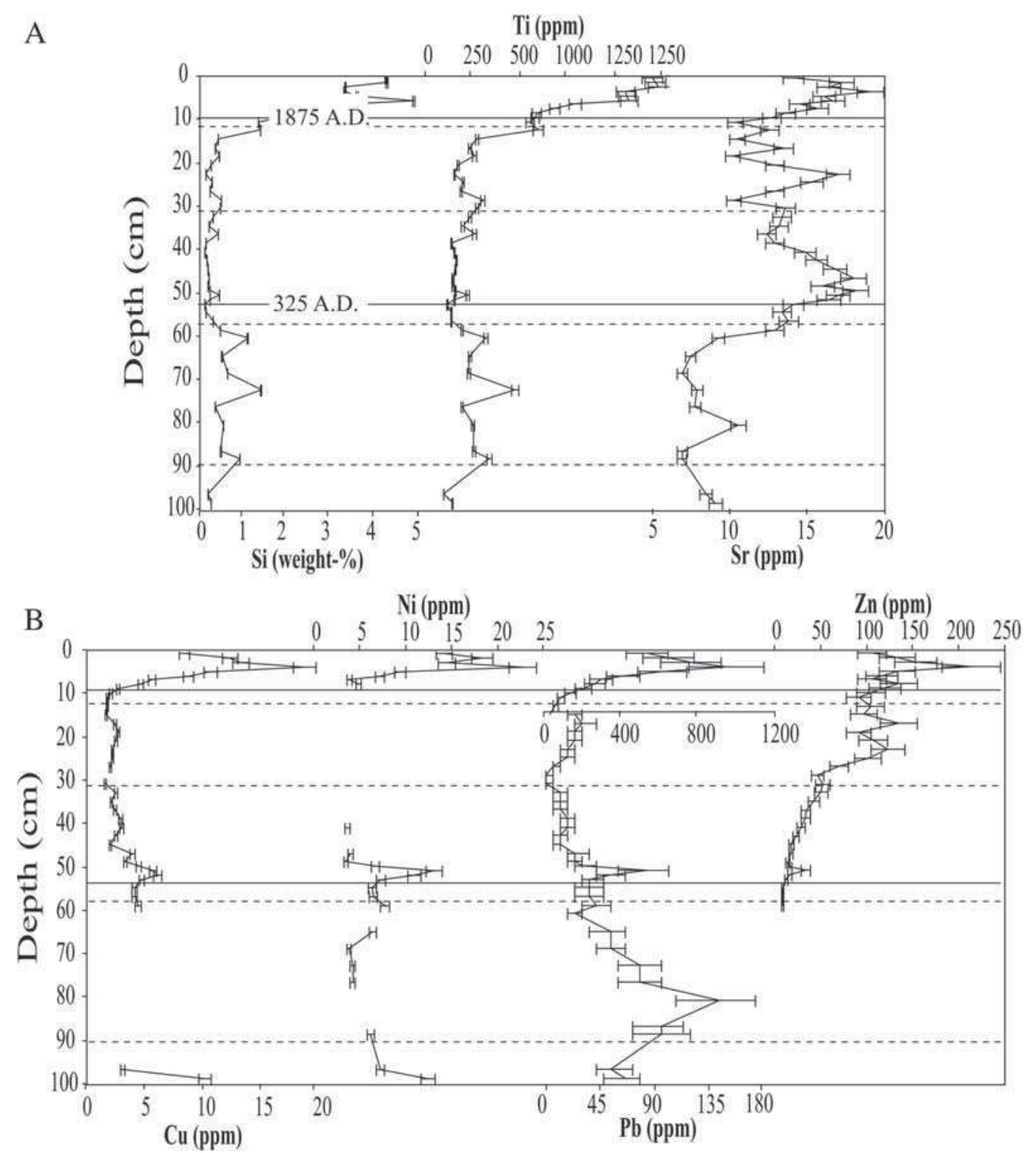

Fig. 2. Concentration variations along depth for Misten bog (in \% for Si and in ppm for other elements, respectively). ${ }^{14} \mathrm{C}$ mean age for $53.5 \mathrm{~cm}$ sample (325 A.D.) and last ${ }^{210} \mathrm{~Pb}(10.5 \mathrm{~cm} ; 1835$ A.D.) sedimentation model derived-date are reported. Dotted lines represent the separation between five major intervals (see Sections 4 and 5 for further details). The $\mathrm{x}$-scale of $\mathrm{Pb}$ profile is changed at $15 \mathrm{~cm}$ depth for visual commodity.

errors following the method of Appleby (op. cit.). These errors were rough estimations since the peat accumulation rate in the recent samples was very low. Results of these analyses are summarized in Table 4.

\subsection{Calculation of enrichment factor}

Lead Enrichment factor (Pb E.F.) was calculated in order to decipher anthropogenic lead inputs from lead of natural (i.e. crustal) origin. In line with previous similar geochemical investigations in peat (e.g. Shotyk et al., 2000; Kempter, 1996), Ti was used as a reference element, because its mineral phases (e.g. titanite, ilmenite or titano-magnetite) are resistant to alteration (Wedepohl et al., 1978; Nesbitt and Markovics, 1997). Lead enrichment factor was obtained as follows: $\mathrm{Pb} \mathrm{E}$. $\mathrm{F} .=\left([\mathrm{Pb}]_{\text {sample }} /[\mathrm{Ti}]_{\text {sample }}\right) /\left([\mathrm{Pb}]_{\text {Upper crust }} /[\mathrm{Ti}]_{\text {Upper crust }}\right)$. Upper crust reference values (17 and $4100 \mathrm{ppm}$ for $\mathrm{Pb}$ and $\mathrm{Ti}$, respectively) were taken from Mc Lennan (2001). 


\section{Results}

\subsection{Elemental content}

Elemental concentrations and lead E.F. of Misten bog are represented along depth in Fig. 2. For graphical presentation purposes, samples from levels $660 \mathrm{~cm}$ and $678 \mathrm{~cm}$ are not shown.

\subsection{1. $\mathrm{Si}, \mathrm{Ti}$}

Both $\mathrm{Si}$ and $\mathrm{Ti}$ display a similar pattern of change with depth. Concentrations are low below $90 \mathrm{~cm}$ depth ([Si] $<\sim 0.4 \%$, [Ti $]<\sim 120 \mathrm{ppm}$ ), and increase to moderately between 90 and $55 \mathrm{~cm}$ depth $(\sim 0.4 \%<[\mathrm{Si}]<\sim 1.5 \%$, $\sim 300<[\mathrm{Ti}]<\sim 1300 \mathrm{ppm})$. These values are followed by a zone of minimum concentrations between $55 \mathrm{~cm}$ and $40 \mathrm{~cm}$ depth $(\sim 0.28 \%<[\mathrm{Si}]<\sim 0.62 \%, \sim 150 \mathrm{ppm}<$ [Ti] $<\sim 500 \mathrm{ppm})$. Between $40 \mathrm{~cm}$ and $20 \mathrm{~cm}$ depth, a slight increase in concentrations can be detected $(\sim 0.30 \%<[\mathrm{Si}]<\sim 0.70 \%, \sim 250 \mathrm{ppm}<[\mathrm{Ti}]<$ $\sim 850 \mathrm{ppm})$. Finally, the concentrations increase significantly towards the surface of the bog $(\sim 0.6 \%<$ $[\mathrm{Si}]<\sim 5 \%, \sim 50<[\mathrm{Ti}]<\sim 500 \mathrm{ppm})$.

\subsection{2. $\mathrm{Sr}$}

Low Sr concentrations $([\mathrm{Sr}]<20 \mathrm{ppm})$ were expected and are typical of peat from ombrotrophic bog (e.g. Shotyk, 2002). The two samples $(660$ and $678 \mathrm{~cm}$ depth) analyzed for natural background $\mathrm{Sr}$ gave a mean concentration of $46 \mathrm{ppm}$, a doubling concentration from the samples above the top meter. This higher concentration reflects the minerotrophic character of the peat, starting to accumulate just above the bottom sediment (loess and quartzite fragments).

\subsection{3. $\mathrm{Cu}, \mathrm{Ni}, \mathrm{Pb}, \mathrm{Zn}$}

Between $100 \mathrm{~cm}$ and $50 \mathrm{~cm}, \mathrm{Cu}$ and $\mathrm{Zn}$ concentration profiles are partially under detection limits (D.L.), and $\mathrm{Ni}$ concentrations are low. $\mathrm{Pb}$ concentrations do however show relatively high values $(32.3 \mathrm{ppm}$ to $139 \mathrm{ppm})$. For the top $50 \mathrm{~cm}$ of the core, values of Ni, $\mathrm{Cu}$ and $\mathrm{Pb}$ display similar trends, with minimum concentrations $([\mathrm{Pb}] \sim 13 \mathrm{ppm},[\mathrm{Zn}] \sim 50 \mathrm{ppm},[\mathrm{Cu}]$ $\sim 1.5 \mathrm{ppm}$ and $[\mathrm{Ni}]<$ D.L.) at around $30 \mathrm{~cm}$ depth, with increased values ([Pb] up to $949 \mathrm{ppm},[\mathrm{Zn}]$ up to $214 \mathrm{ppm},[\mathrm{Cu}]$ up to $18.7 \mathrm{ppm}$ and [Ni] up to $22.8 \mathrm{ppm}$ ) toward the surface.

\subsection{Lead isotopic ratios}

Profiles of lead isotopic ratios vs. depth are shown in Fig. 3. ${ }^{208} \mathrm{~Pb} /{ }^{204} \mathrm{~Pb},{ }^{207} \mathrm{~Pb} /{ }^{204} \mathrm{~Pb},{ }^{206} \mathrm{~Pb} /{ }^{204} \mathrm{~Pb}$ isotopic ratios exhibit similar trends: poorly radiogenic values $\left({ }^{208} \mathrm{~Pb} /{ }^{204} \mathrm{~Pb}>38.200,{ }^{207} \mathrm{~Pb} /{ }^{204} \mathrm{~Pb}\right.$ around 15.615 , $\left.{ }^{206} \mathrm{~Pb} /{ }^{204} \mathrm{~Pb}>18.250\right)$ between 100 and $90 \mathrm{~cm}$, and comparatively unradiogenic values $\left(37.931<{ }^{208} \mathrm{~Pb} /{ }^{204} \mathrm{~Pb}<\right.$ $38.120,15.594<{ }^{207} \mathrm{~Pb} /{ }^{204} \mathrm{~Pb}<15.608,17.990<$ $\left.{ }^{206} \mathrm{~Pb} /{ }^{204} \mathrm{~Pb}<18.165\right)$ between $60 \mathrm{~cm}$ and $30 \mathrm{~cm}$. Then ratios shift toward more radiogenic values between $30 \mathrm{~cm}$ and $10 \mathrm{~cm}\left(38.150<{ }^{208} \mathrm{~Pb} /{ }^{204} \mathrm{~Pb}<38.200,15.605<\right.$ $\left.{ }^{207} \mathrm{~Pb} /{ }^{204} \mathrm{~Pb}<15.615,18.200<{ }^{206} \mathrm{~Pb} /{ }^{204} \mathrm{~Pb}<18.300\right)$ and in the top $10 \mathrm{~cm}$ show a sudden shift towards low isotopic values $\left({ }^{208} \mathrm{~Pb} /{ }^{204} \mathrm{~Pb}<37.950,{ }^{207} \mathrm{~Pb} /{ }^{204} \mathrm{~Pb}<15.600\right.$, $\left.{ }^{206} \mathrm{~Pb} /{ }^{204} \mathrm{~Pb}<18.015\right)$.

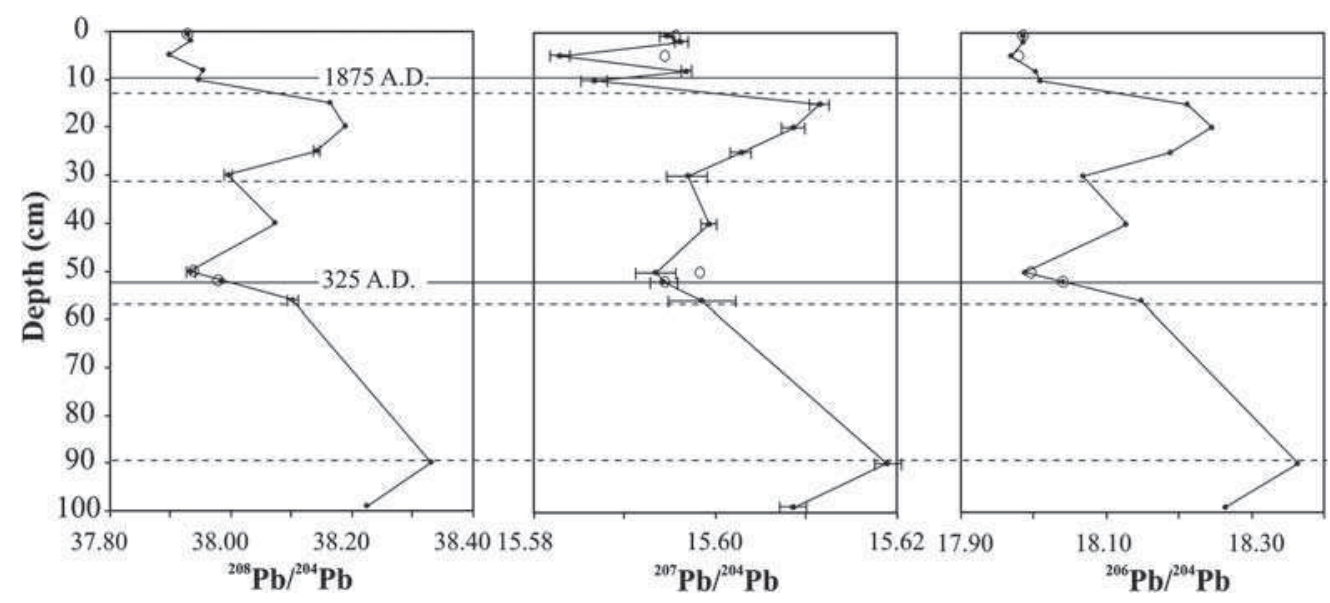

Fig. 3. ${ }^{208} \mathrm{~Pb} /{ }^{204} \mathrm{~Pb},{ }^{207} \mathrm{~Pb} /{ }^{204} \mathrm{~Pb},{ }^{206} \mathrm{~Pb} /{ }^{204} \mathrm{~Pb}$ isotopic ratio vs. depth. Open circles are replicates. ${ }^{14} \mathrm{C}$ mean age for $53.5 \mathrm{~cm}$ sample (325 A.D.) and last ${ }^{210} \mathrm{~Pb}(10.5 \mathrm{~cm}$; 1835 A.D.) sedimentation model derived-date are reported. Dotted lines represent the separation between five major intervals (see Sections 4 and 5 for more details). Background samples $(660 \mathrm{~cm}$ and $678 \mathrm{~cm})$ are not represented. 


\section{Discussion}

\subsection{Si and $T i$}

\subsubsection{Historical and archaeological background in East Belgium}

During the second Iron age (480 B.C. to 27 B.C.), Celts were established in South Belgium (Graillet, 1998; Remy, 1981). These people were the first important farmers and land clearers in the area, but their agricultural activities remained small compared to those of the following Roman period (Ferdière, 1988). They were however known their mining activities. They developed gold extraction from, river overbank, river sediments, and arkose mines for making grinds (Cauuet, 2005; Remy, 1981; Graillet, 1998). Archeological evidence of early gold mining in Southeast Belgium are attested by more than 1000 mining waste mounds (fluvial deposits) dumped near the source, mainly rivers and streams (Cauuet, 2005 and reference therein). Two of these mounds are found overlying peat. These provide respective radiocarbon age ranges of 120 B.C.-140 A.D. (Dumont, 1979; Gilot, 1997) and 400 B.C.-200 B.C. (Dumont, 1980; Gilot, 1997). Though it would be beneficial to confirm these data with further dates and field investigations, there are in good agreement with the Second Iron age and the Early Roman Empire.

Romans then extended land clearance for pasture and cultivation. Further evidence for pasture are shown in several pollen diagrams from peat sequences from the Hautes Fagnes. Indeed, Plantago lanceolata (considered as the best indication for pasture) made a first occurence during the Neolithic, becoming more abundant during the Gallo-Roman period (Damblon, 1994). Cereal pollens indicative of increase anthropogenic activities were also found in significant amounts in the Hautes Fagnes representative of the Roman period (Damblon, 1994; Gotjé et al., 1990). Additional archaeological remnants from the Roman period are prolific in Belgium (Fig. 1B). Evidence of early mining activities include an open-air gold and arkose mine with grind remnants (Fig. 1B.2), and a mine gallery (Fig. 1B.3). (Cauuet, 2005; Remy, 1981). The open air mine is still not well dated and requires further archaeological investigation. Actually, the only link to the Roman period is made by field comparison with similar sites in France (Cauuet, 2005). In the mine gallery, a piece of wood used once used for propping up the mine shaft was dated to an age interval of 240 A.D.440 A.D. (Cauuet, 2005) which corresponds to the Late Roman Empire period. However, as no evident archaeological artifacts of Roman facture have been found in this gallery, the age of gold extraction should be taken with caution. However, this piece of wood could represent later re-occupation of the mine. No further archaeological artifact of Roman age have been found to support this. Therefore the exact age of the extraction is still uncertain. There is no further evidence for metal mining or smelting Romans in the area. Moreover, from the 4th century A.D., a decline of the agricultural activities is observed in Belgium (Brulet, 1990). The Early Middle Ages were characterized by a more extended extractive industry and $\mathrm{Pb}-\mathrm{Zn}$ ore extraction occurred (Dejonghe, 1998; Renson et al., 2005; see also Section 4.2.1). Further Si and Ti inputs to the bog are due to the extensive clearance and mining exploitation of sedimentary rocks, associated with the second industrial revolution.

\subsubsection{Chronological control}

The chronology of the core is based on dates obtained from radiocarbon dating, palynology and ${ }^{210} \mathrm{~Pb}$. Only one sample at $53.5 \mathrm{~cm}$ has been ${ }^{14} \mathrm{C}$ dated. This gave an age of $326 \pm 76$ cal A.D. (Late Roman Empire). The results of pollen profiles from previous studies in the same bog were used to delineate critical periods of human activities (Hindryckx, 2000; Hindryckx and Streel, 2000; Gérard, 2004; Goormaghtigh, 2005). All cores used for palynology were retrieved within $100 \mathrm{~m}$ of the core site used in this study, where peat thickness extended more than $6.5 \mathrm{~m}$ (see Fig. 1). In all pollen diagrams used, the top meter is representative of the young Subatlanticum Zone XI (as defined by Firbas, 1939), covering roughly the last 2000 years. This zone is characterized by abundant pollen maxima of Fagus (beech tree) and significant presence of Carpinus (hornbeam) (>1-2\%). These palynological characteristics have been controlled in the present core by Gérard (2004) and Goormaghtigh (2005). Coincidence of abundant Fagus and start of Carpinus has been recently dated at 150 A.D. by Streel et al. (2006) in a peat bog a few kilometers to the South-East of the Misten bog. In the Misten bog, Hindryckx and Streel (2000) dated the third peak of Fagus at around 1140土 125 A.D. This third maximum of Fagus is found at $30 \mathrm{~cm}$ depth in the present core (Goormaghtigh, 2005), providing a chronological indicator for the Middle Ages.

With the date of 150 A.D. around $95 \mathrm{~cm}$ depth (Streel et al., 2006), our new date of $326 \pm 76$ A.D. at $53.5 \mathrm{~cm}$, the date of $1140 \pm 125$ A.D. (Hindryckx and Streel, 2000) around $30 \mathrm{~cm}$ depth, and finally our ${ }^{210} \mathrm{~Pb}$ age model for the subsurface, a rather accurate age-depth relationship can be accepted. 

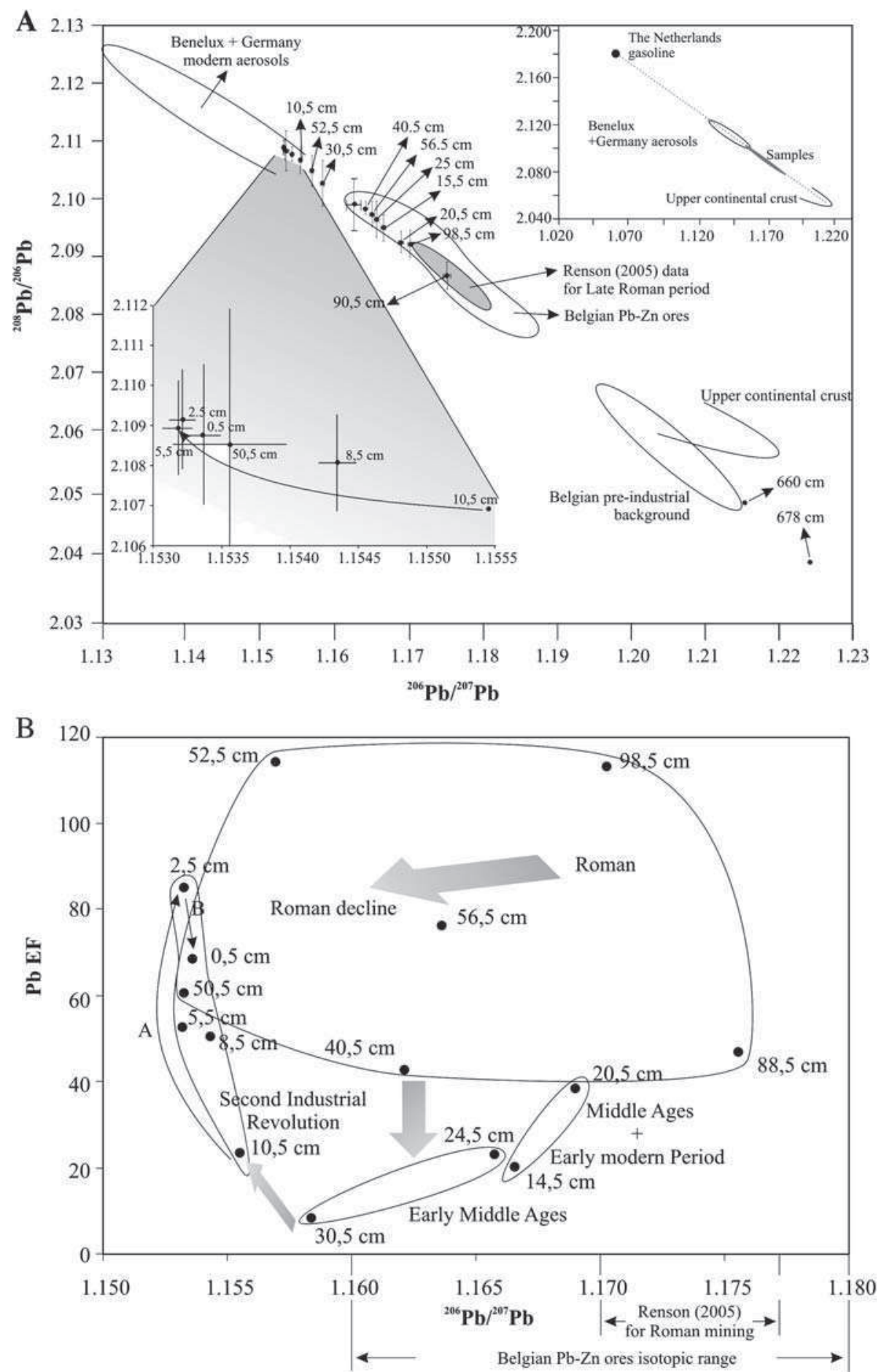

Fig. 4. ${ }^{206} \mathrm{~Pb} /{ }^{207} \mathrm{~Pb}$ vs. ${ }^{208} \mathrm{~Pb} /{ }^{206} \mathrm{~Pb}$ isotopic ratios, and ${ }^{206} \mathrm{~Pb} /{ }^{207} \mathrm{~Pb}$ vs. Pb E.F. Modern industrial Belgian aerosols from Bollhöfer and Rosman (2001), and Sonke et al. (2002). Belgian ore data from Cauet et al. (1982) and Dejonghe (1998). Data from archeological site from Renson et al. (2007) are also reported. Belgian pre-industrial sediment from Sonke et al. (op. cit.). Upper continental crust field from Millot et al. (2004), Hemming and McLennan (2001), Grousset et al. (1994) and Asmeron and Jacobsen (1993). Gasoline from The Netherlands from Hopper et al. (1991). 


\subsubsection{Can Si and Ti measurements provide evidence for} Roman activities?

$\mathrm{Si}$ and $\mathrm{Ti}$ increase significantly between 90 and $55 \mathrm{~cm}$ depth. It has already been shown that land clearance, farming, and following erosion could play a role in $\mathrm{Si}$ and $\mathrm{Ti}$ inputs to a peat bog (Holynska et al., 1998; Hölzer and Hölzer, 1998; Görres, 1993). An increase in $\mathrm{Si}$ and $\mathrm{Ti}$ often reflects an increase in soil dust inputs (e.g. Holynska et al., 1998; Shotyk et al., 1998; Görres, 1993). In support for this in our core, the cereal pollen content increase between 80 and $60 \mathrm{~cm}$ (Goormaghtigh, 2005), favoring the hypothesis of cultivation. Arkose mining and gold prospecting could also have played a role. However, with little known about the age of these mines, we conclude that it is most likely that the primary input of $\mathrm{Si}$ and Ti-bearing particle are due to extensive Roman agricultural activities.

\subsection{Origin of heavy metals through the last 2000 years}

The origin of lead and associated heavy metals can be established both by ${ }^{208} \mathrm{~Pb} /{ }^{207} \mathrm{~Pb}$ vs. ${ }^{206} \mathrm{~Pb} /{ }^{207} \mathrm{~Pb}$ diagram and $\mathrm{Pb}$ E.F. coupled with ${ }^{206} \mathrm{~Pb} /{ }^{207} \mathrm{~Pb}$ isotopic ratio (Fig. 5). The principle being the isotopic signature changes with origin of particles form the upper continental crust, through Belgian ores and toward a signature of modern Benelux aerosols (see Fig. 4 for references). The lowermost samples $(660 \mathrm{~cm}$ and $678 \mathrm{~cm}$ ) show good agreement with upper continental crust values (Millot et al., 2004; Hemming and McLennan, 2001; Grousset et al., 1994; Asmeron and Jacobsen, 1993) and Belgian pre-industrial background sediments from Sonke et al. (2002). However, the least radiogenic values of ${ }^{208} \mathrm{~Pb} /{ }^{207} \mathrm{~Pb}$ and ${ }^{206} \mathrm{~Pb} /{ }^{207} \mathrm{~Pb}$ ratios are still far from The Netherlands gasoline (similar to Belgian gasoline) values $\left({ }^{208} \mathrm{~Pb} /{ }^{206} \mathrm{~Pb}=2.28 \pm 0.013\right.$, $\left.{ }^{206} \mathrm{~Pb} /{ }^{207} \mathrm{~Pb}=1.062 \pm 0.019\right)$ reported by Hopper et al. (1991).

\subsubsection{Roman Empire}

In the core $\mathrm{Pb}$ enrichment factors display a wide range of variation during the Early Roman Empire with isotopic ratios being very low (see Fig. 5, samples at $98.5 \mathrm{~cm}$ and $88.5 \mathrm{~cm}$ depth). During the Roman Empire, and particularly towards the upper end $(60 \mathrm{~cm}-40 \mathrm{~cm})$ $\mathrm{Pb}$ E.F. are quite high (up to 110 ) and ${ }^{206} \mathrm{~Pb} /{ }^{207} \mathrm{~Pb}$ ratio shows lower radiogenic values $\left({ }^{206} \mathrm{~Pb} /{ }^{207} \mathrm{~Pb}\right.$ up to 1.154).

It is known that Romans mined and extracted a wide range of ores all over NW Europe and around the Mediterranean Sea, increasing significantly the amount of aerosol which has a wide range of $\mathrm{Pb}$-isotopic composition particles in the air. However, in the Misten bog, it seems that a more local influence has been recorded. Indeed, the isotopic values of samples from $98.5 \mathrm{~cm}$ to $50 \mathrm{~cm}$ depth show good agreement with the isotopic field of the Belgian $\mathrm{Pb}-\mathrm{Zn}$ ores (Fig. 4).

In Belgium, there is no historical, archaeological or field evidence for Roman $\mathrm{Pb}-\mathrm{Zn}$ mining. However, Renson (2005) and Renson et al. (2007), in their study on a peat column taken nearby an archaeological site constituted by a Roman to Merovingian road in the Hautes Fagnes, found and dated very high $\mathrm{Zn}$ concentrations (up to $1000 \mathrm{ppm}$ ) associated with peaks in lead concentration (up to $80 \mathrm{ppm}$ ). Such high concentration clearly reflect a local pollution linked to the road (Renson,

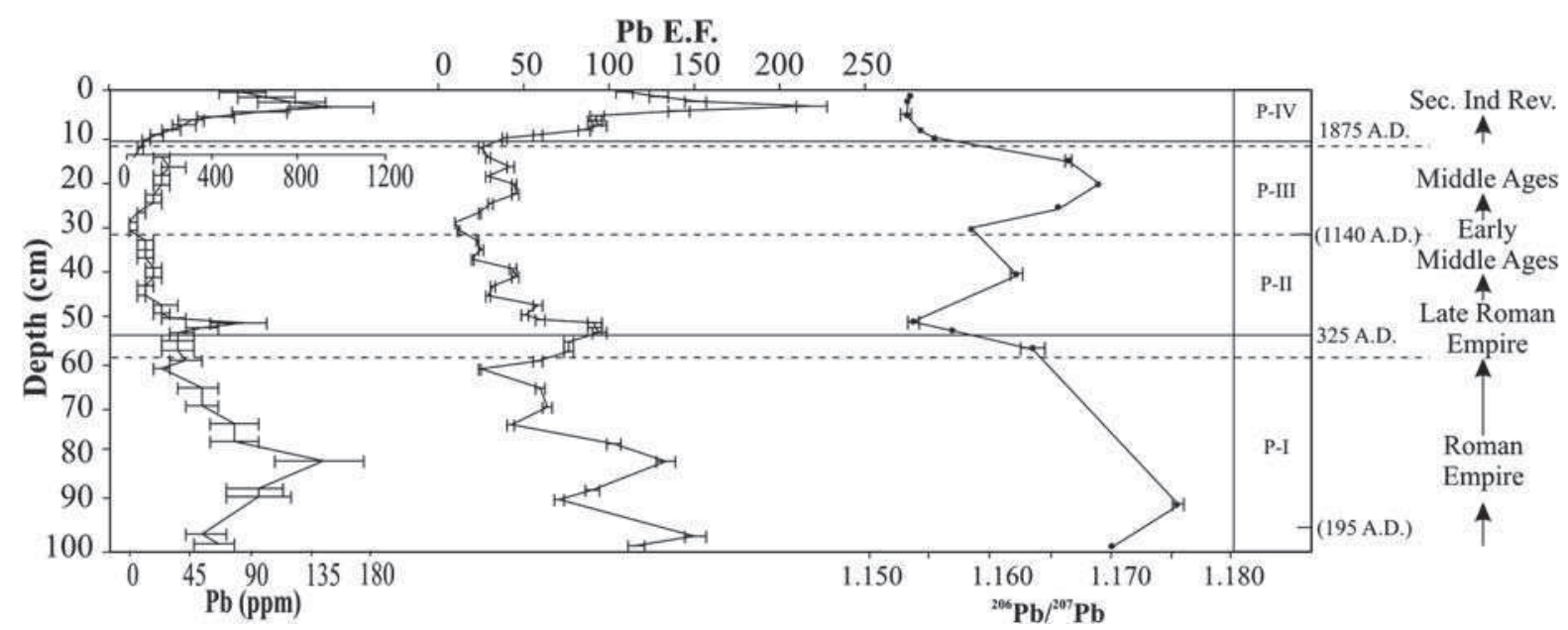

Fig. 5. Summary of major $\mathrm{Pb}, \mathrm{Pb}$ E.F. and ${ }^{206} \mathrm{~Pb} /{ }^{207} \mathrm{~Pb}$ in the first meter Misten bog and interpretation of historical intervals. The $\mathrm{x}-\mathrm{scale}$ of $\mathrm{Pb}$ profile has been changed at $15 \mathrm{~cm}$ depth for visual clarity. 
2005). Moreover, the lead isotopic composition $\left({ }^{208} \mathrm{~Pb} /\right.$ $\left.{ }^{207} \mathrm{~Pb} \sim 1.17-1.18,{ }^{208} \mathrm{~Pb} /{ }^{206} \mathrm{~Pb} \sim 2.08-2.10\right)$ of the $\mathrm{Pb}$ and $\mathrm{Zn}$-contaminated levels found by Renson (2005) and Renson et al. (2007) are in very good agreement with isotopic composition of $\mathrm{Pb}-\mathrm{Zn}$ ores located $15 \mathrm{~km}$ northwards to the Hautes Fagnes Plateau. These new data suggests that local $\mathrm{Pb}-\mathrm{Zn}$ ores from the Verviers area (for location see Fig. 1.) were extracted and transported through the Hautes Fagnes Plateau from around A.D. 150 (Renson, 2005).

In conclusion, although there is no field archaeological evidence for Roman lead-zinc ore mining in Belgium, this study from this study and from Renson (2005) and Renson et al. (2007) show significant support for mining of $\mathrm{Pb}-\mathrm{Zn}$ ores in Belgium during the Roman Empire.

\subsubsection{Late Roman Empire and Early Middle Ages}

Following the Roman Empire, the next phase of change is characterized by a decrease in $\mathrm{Pb}$ enrichment factors ( $\sim 40 \mathrm{~cm}-25 \mathrm{~cm}$ depth), reflecting the decline of the Roman mining activities. Minimum $\mathrm{Pb}$ E.F. values (less than 20) are observed between depth of $35 \mathrm{~cm}$ and $25 \mathrm{~cm}$. This Early Middle Ages period has already been well documented in other European peat bogs (e.g. Le Roux et al., 2004). Its main geochemical characteristic in peat bogs is a wide range of $\mathrm{Pb}$ isotopic composition, but low $\mathrm{Pb}$ E.F., as various ores were mined across Europe, but in smaller quantities, as suggested in the estimation from Settle and Patterson (1980) and the data from Hong et al. (1994). Here however, although mining industries were growing up across Europe, the most probable source of anthropogenic dust is the Belgian ore bodies (Fig. 4 above).

This period is followed by the Classic and Late Middle Ages (i.e. 900 A.D. to 1450 A.D.), and the Early modern period (i.e. 1450A.D. to 1700A.D.). This time period is represented by $\mathrm{Pb}$ isotopic signatures which also match well with Belgian ores. The extraction of these ores are well documented in historical texts back to Middle Ages (Dejonghe, 1998), adding a new source for $\mathrm{Pb}$ inputs to Belgian bogs.

\subsubsection{Industrial revolution}

Between $10 \mathrm{~cm}$ (1835 A.D.) and $2.5 \mathrm{~cm}$ (1964 A.D.), $\mathrm{Pb}$ E.F. increase in parallel with a small decrease of ${ }^{206} \mathrm{~Pb} /{ }^{207} \mathrm{~Pb}$ ratio. During this period enhanced local $\mathrm{Pb}-\mathrm{Zn}$ ore processing ( 1840 A.D., Dejonghe, 1998) together with coal mining and burning (Gaier, 1988), and the introduction of leaded gasoline, allow the addition of tremendous amounts of anthropogenic aerosols in the atmosphere. Around 1975, the estimated anthropogenic $\mathrm{Pb}$ was about 4240 metric tons per annum (p.a.) in Belgium, 2263 metric tons p.a. in The Netherlands, 18,860 metric tons p.a. in France, and 16,500 metric tons p.a. in nearby Germany (cumulated FDR and DDR, von Storch et al., 2003). This strong increase in atmospheric pollution is recorded in the Misten bog by a marked increase in $\mathrm{Pb}$ from $89.1 \mathrm{ppm}$ at $10.5 \mathrm{~cm}$ to $949 \mathrm{ppm}$ at $3.5 \mathrm{~cm}$ depth. This is followed by related heavy metals concentrations (from $10.5 \mathrm{~cm}$ to $3.5 \mathrm{~cm}$ depth, $\mathrm{Cu}$ from $1.8 \mathrm{ppm}$ to $18.7 \mathrm{ppm}$, Ni from $<$ D.L. to $22.8 \mathrm{ppm}, \mathrm{Zn}$ from $91.6 \mathrm{ppm}$ to $214 \mathrm{ppm}$ ), together with an increase of $\mathrm{Pb}$ E.F. (from 39 to 218) and shifts in lead isotopic ratios $\left({ }^{206} \mathrm{~Pb} /{ }^{207} \mathrm{~Pb}_{15} \mathrm{~cm}=1.1666\right.$, then $\left.{ }^{206} \mathrm{~Pb} /{ }^{207} \mathrm{~Pb}_{2} \mathrm{~cm}=1.1532\right)$. Reduced radiogenic ${ }^{206} \mathrm{~Pb} /{ }^{207} \mathrm{~Pb}$ values do not, however, predate the maximum $\mathrm{Pb}$ concentrations and $\mathrm{Pb}$ E.F. as previously reported in peat cores from Denmark, Greenland (Shotyk et al., 2003) and the Faeroe Islands (Shotyk et al., 2005). Shotyk et al. (2003) argued that in Denmark or Greenland, this shift is linked to the predominance of coal burning more than the total $\mathrm{Pb}$ pollution. It is therefore likely that, in the Hautes Fagnes, leaded gasoline accounts at least as much as the other $\mathrm{Pb}$ sources (industries and coal burning) for the $\mathrm{Pb}$ input in this area. This is further corroborated by observations from von Storch et al. (2003), who reported that among the diverse anthropogenic $\mathrm{Pb}$ sources, leaded gasoline is the main one, increasing from its introduction (1931 A.D.) and reaching a maximum in the early 1970's. During this period, leaded gasoline accounted for $75 \%$ of the total atmospheric lead emission across Europe. In the same study, decadal estimations of anthropogenic $\mathrm{Pb}$ emissions over the last 50 years show a maximum around 1965, which also agrees with our findings.

\subsubsection{Unleaded gasoline}

The phasing out of lead in gasoline began in 1972 in Europe. Indeed, during the European oil crisis, Germany began to adopt policies to reduce lead content of gasoline. This was followed by the first EU regulation (1981). Between 1984 and 1989, unleaded gasoline was progressively introduced across Europe. As a result, atmospheric $\mathrm{Pb}$ emissions began to decrease slightly in the second half of the 1960's, then suddenly by the mid-1970's (von Storch et al., 2003). Although there are slight discrepancies of age in our peat core due to sampling intervals $(1 \mathrm{~cm}$ representing a mean of 20 years above $3 \mathrm{~cm}$ depth, see Table 2), this decrease in $\mathrm{Pb}$ concentration and $\mathrm{Pb}$ E.F. is marked in the upper samples from above $3.5 \mathrm{~cm}$ depth, and is therefore representative for post-A.D. 1950. These records also correspond with diverse records from 
Belgium (Petit et al., 1984), France (Rosman et al., 2000; Arnaud et al., 2004), and Switzerland (Kober et al., 1999; Shotyk et al., 1998).

\section{Conclusions}

Geochemical and lead isotopic derived from the top meter of peat from the Misten peat bog (Fig. 5) record four major periods of pollution. Firstly the Roman Empire (P-I), represented between $100 \mathrm{~cm}$ and $\sim 57 \mathrm{~cm}$, is characterized by local pollution sources from $\mathrm{Pb}-\mathrm{Zn}$ ores mining and agriculture activities. Between $\sim 57 \mathrm{~cm}$ and $\sim 30 \mathrm{~cm}$, the geochemical profiles show a decline in the Roman activities and the transition to Early Middle Ages (P-II). The Middle Ages and Early modern period ( $\sim 30 \mathrm{~cm}$ to $\sim 104 \mathrm{~cm}, \mathrm{P}-\mathrm{III})$ rapidly give way to the modern industrial Revolution (from $\sim 10 \mathrm{~cm}$ to the actual surface, P-IV) in which lead gasoline accounts for at least $50 \%$ of the lead pollution.

This study provides the opportunity to complete the European datasets for pollution reconstruction in continental environments.

\section{Acknowledgements}

We are very grateful to Guy Bologne and Sophie Leclercq for the XRF analysis, M. Streel and L. Leclercq their advice and knowledge of the Hautes Fagnes Plateau. Claude Maershalk is thanked for assistance in the clean lab at ULB and for the MC-ICP-MS measurements. Xavier Boës was of great help during the coring. We are especially grateful to Maurice Streel for fruitful discussions and reference searching concerning pollen diagrams, and to Béatrice Cauuet (C.N.R.S., Univ. Toulouse Le Mirail, France) and Muriel van Ruymbeke (European Center for Archeometry, Univ. Liège, Belgium) for having accurately commented and improved the archeological background. Pascal Mertes (DNF-Belgian Forest and Nature Ministry) is also warmly thanked for providing us the official authorization for coring the Misten bog. We finally thank Maria Gehrels (Univ. Plymouth, U.K.) and one anonymous reviewer for English smoothing. This work was funded by NSRF (Belgian Scientific Research Foundation) credits. François De Vleeschouwer is FRIA fellowship.

\section{References}

Arnaud F, Revel-Rolland M, Bosch D, Winiarski T, Desmet M, Tribovillard N, et al. A 300 year history of lead contamination in Northern French Alps reconstructed from distant lake sediment records. J Environ Monit 2004;6:1-10.

Appleby PG. Chronostratigraphic techniques in recent sediments. Tracking environmental change using lake sediments, vol. 1.
Volume 1: Basin analysis, coring and chronological techniques; 2001. p. 171-203.

Asmeron Y, Jacobsen SB. The Pb isotopic evolution of the Earth: inferences from river water suspended loads. Earth Planet Sci Lett 1993;115:245-56.

Belokopytov IE, Beresnevich VV. Giktorf's peat borers. Torf. prom. 1955;8:9-10.

Bollhöfer A, Rosman KJR. Isotopic source signatures for atmospheric lead: the Northern Hemisphere. Geochimic Cosmochim Acta 2001;65:1727-40.

Boyd RS. Ecology of metal hyperaccumulation. New Phytol 2004;162: 563-7.

Brulet R. La gaule septentrionale au Bas-Empire: occupation du sol et défense du territoire dans l'arrière pays du limes aux IVè et Vè siècles. Trier Zeitschrift für Geschichte und Kunst des Trierer Landes und seiner Nachbargebiete, Trêves; 1990. [In French].

Cauet S, Weis D, Herbosh A. Genetic study of Belgian lead zinc mineralizations in carbonate environments through lead isotope geochemistry. Bulletin du BRGM; 1982. p. 329-41. [Section II].

Cauuet B. Les mines d'or antiques d'Europe hors péninsule Ibérique. État des connaissances et travaux récents, Mines et métallurgies dans l'Antiquité. Etat des recherches-Dossier thématique, 67. vol. Pallas; 2005. p. 241-91. Toulouse [In French].

Corbiau M-H. Les voies romaines: des performances techniques au service de la politique. Les Cahiers de l'Urbanisme, vol. 19-20; 1998. p. 124-6. [In French].

Dejonghe L. Zinc-lead deposits of Belgium. Ore Geol. Rev. 1998;12:329-54.

Damblon F. Les dépôts tourbeux et l'histoire de la végétation sur le plateau des Hautes-Fagnes (Belgique). Ann Soc Géol Belg 1994;117:259-76 [In French].

Dunlap CE, Steinnes E, Flegal AR. A synthesis of lead isotopes in two millennia of European air. Earth Planet Sci Lett 1999;167:81-8.

Dumont J-M. Première datation d'un tertre d'orpaillage en Ardenne. Glain et Salm, Haute Ardenne, vol. 10; 1979. p. 87-8. [In French].

Dumont J-M. Orpaillage celtique à l'époque de la Tène au Plateau des Tailles. Glain et Salm, Haute Ardenne, vol. 13; 1980. p. 42-5. [In French].

Ferdière A. Les campagnes en Gaule romaine.T.1. Les hommes et l'environnement en Gaule rurale (52 av. J.-C.-486 ap. J.-C.), Coll. Hespérides. Paris: Errance; 1988. 301 pp. [In French].

Firbas F. Vegetationsentwicklung unnd Klimawandel in der mitteleuropäischen Spät-und Nacheiszeit. Natuurwischenscraften Die Naturwissenschaften, vol. 27; 1939. p. 81-108.

Gaier C. Huit siècles de houillerie liégeoise. Histoire des hommes et du charbon à Liège. Editions du Perron, Belgium: Liège; 1988. 264 pp. [In French].

Galer SJG, Abouchami W. Practical applications of lead triple spiking correction of instrumental mass discrimination. Mineral. Mag. 1998;62A:491-2.

Gérard L. Suivi des apports atmosphériques en plomb au cours de l'Holocène. Bachelor thesis. University of Liège, Belgium, 2004; 84 pp.+annexes. In French.

Goormaghtigh C. Suivi des apports atmosphériques en métaux lourds durant la période Subatlantique (depuis 850 ans), dans un milieu continental pollué: enregistrement de deux tourboères des Hautes Fagnes (Belgique). Bachelor thesis. University of Liège, Belgium, 2005; 102 pp.+annexes. In French.

Görres $\mathrm{M}$. The $\mathrm{Pb}, \mathrm{Br}$, and $\mathrm{Ti}$ content in peat bogs as indicator for recent and past depositions. Naturwissenschaften 1993;80: $333-5$. 
Gilot E. Index général des dates Lv. Laboratoire du carbone 14 de Louvain/Louvain-la-Neuve. Stud Praehist Belgica 1997;7 [LiègeLeuven. In French].

Gotjé W, van Wayjen MCA, Van Geel B. A palynological study of a Holocene deposit from Gran Bongard (Hautes-Fagnes, Belgium). Geol Mijnb 1990;69:227-41.

Govindaraju K, de la Roche H. Rapport (1966-1976) sur les éléments en trace dans trois roches standardes géochimiques du CRPG: basalte BR et granites GA et GH. Geostand Newsl 1977;1:67-100.

Graillet L. De l'or en Ardenne. In: Graillet L, editor. Belgique: Liège; 1998. 106 pp. [In French].

Grousset FE, Quetel CR, Thomas B, Buatmenard P, Donard OFX, Bucher A. Transient $\mathrm{Pb}$ isotopic signatures in the WesternEuropean atmosphere. Environ Sci Technol 1994;28:1605-8.

Hemming SR, McLennan SM. Pb isotope compositions of modern deep sea turbidites. Earth Planet Sci Lett 2001;184:489-503.

Hindryckx M-N. Evolution régressive récente de la végétation des tourbières hautes à sphaignes en Haute Ardenne (Hautes-Fagnes, Belgique). PhD Thesis, University of Liège, Belgium, 2000. 125 pp.+annexes. In French.

Hindryckx M-N, Streel M. L'altération des bords de la tourbière active du Misten par l'exploitation de la tourbe pourrait dater du début du 14e siècle. Hautes Fagnes 2000;4:95-101 [In French].

Holynska B, Ostrachowicz B, Ostrachowicz J, Samek L, Wachniew P, Obidowicz A, et al. Characterisation of $210 \mathrm{~Pb}$ dated peat core by various X-ray fluorescence techniques. Sci Total Environ 1998;218:239-48.

Hölzer A, Hölzer A. Silicon and titanium in peat profiles as indicators of human impacts. The Holocene 1998;8:685-96.

Hong S, Candelone J-P, Patterson CC, Boutron CF. Greenland ice evidence of hemispheric lead pollution two millenia ago by greek and Romand civilizations. Science 1994;265:1841-3.

Hopper JF, Ross HB, Sturges WT, Barrie LA. Regional source discrimination of atmospheric aerosols in Europe using the isotopic composition of lead. Tellus 1991;43B:45-60.

Jowsey PC. An improved peat sampler. New Phytol 1965;65:245-8.

Kempter H. Der Verlauf des anthropogenen elementeintrags in Regenwassermoore des westlichen Mitteleuropas während des jüngeren Holozäns. Paläoklimaforschung 1996;26:309.

Kempter H, Frenzel B. The local nature of anthropogenic emission sources on the elemental content of nearby ombrotrophic peat bogs, Vulkaneifel, Germany. Sci Total Environ 1999;241: $117-28$.

Kober B, Wessels M, Bollhofer A, Mangini A. Pb isotopes in sediments of Lake Constance, Central Europe constrain the heavy metal pathways and the pollution history of the catchment, the lake and the regional atmosphere. Geochimic Cosmochim Acta 1999;63:1293-303

Krachler M, Mohl C, Emons H, Shotyk W. Atmospheric deposition of $\mathrm{V}, \mathrm{Cr}$, and $\mathrm{Ni}$ since the Late Glacial: effects of climatic cycles, human impacts, and comparison with crustal abundances. Environ Sci Technol 2003;37:2658-67.

Kylander ME, Weiss DJ, Martinez Cortizas A, Spiro B, GarciaSanchez R, Coles BJ. Refining the pre-industrial atmospheric $\mathrm{Pb}$ isotope evolution curve in Europe using an 8000 year old peat core from NW Spain. Earth Planet Sci Lett 2005;240:467-85.

Le Roux G, Aubert D, Stille P, Krachler M, Kober B, Cheburkin A, et al. Recent atmospheric $\mathrm{Pb}$ deposition at a rural site in southern Germany assessed using a peat core and snowpack, and comparison with other archives. Atmos Environ 2005;39:6790-801.

Le Roux G, Weiss D, Grattan J, Givelet N, Krachler M, Cheburkin A et al. Identifying the sources and timing of ancient and medieval atmospheric lead pollution in England using a peat profile from Lindow bog, Manchester. J Environ Monit 2004;6:502-10.

Martinez-Cortizas A, García-Rodeja E, Pontevedra-Pombal X, Nóvoa Muñoz J, Weiss D, Cheburkin AK. Atmospheric $\mathrm{Pb}$ deposition in Spain during the last 4600 years recorded by two ombrotrophic peat bogs and implications for the use of peat as archives. Sci Total Environ 2002;292:33-44.

Mc Lennan T. Relationships between the trace element composition of sedimentary rocks and upper continental crust. Geochem Geophys Geosyst 2001;2 2000GC000109.

Mighall TM, Abrahams PW, Grattan JP, Hayes D, Timberlake S, Forsyth S. Geochemical evidence of atmospheric pollution derived from prehistoric copper mining at Copa Hill, Cwmystwyth, midWales, UK. Sci Total Environ 2002;292:69-80.

Millot R, Allègre C-J, Gaillardet J, Roy S. Lead isotopic systematics of major river sediments: a new estimate of the $\mathrm{Pb}$ isotopic composition of the Upper Continental Crust. Chem Geol 2004;203:75-90.

Monna F, Hamer K, Lévêque J, Sauer M. Pb isotopes as a reliable marker of early mining and smelting in the Northern Harz province (Lower Saxony, Germany). J Geochem Explor 2000;68: 201-10.

Nesbitt WH, Markovics G. Weathering of granodioritic crust, longterm storage of elements in weathering profiles, and petrogenesis of siliciclastic sediments. Geochim Cosmochim Acta 1997;61 (8):1653-70.

Novak M, Emmanuel S, Vile MA, Erel Y, Véron A, Paces T, et al. Origin of lead in eight Central European peat bogs determined from isotope ratios, strengths, and operation times of regional pollution sources. Environ Sci Technol 2003;37:437-45.

Persh F(). Zur postglazialen Wald-und Moorentwicklung im Hohen Venn. Decheniana 1950;104:81-93 [In German].

Petit D, Mennessier JP, Lamberts L. Stable lead isotopes in pond sediments as tracer of past and present atmospheric lead pollution in Belgium. Atmos Environ 1984;18:1189-93.

Rausch N, Ukonmaanaho L, Nieminen TM, Krachler M, Shotyk W. Porewater evidence of metal $(\mathrm{Cu}, \mathrm{Ni}, \mathrm{Co}, \mathrm{Zn}, \mathrm{Cd})$ mobilization in an acidified, ombrotrophic peat bog impacted by a smelter, Harjavalta, Finland. Environ Sci Technol 2005;39:8207-13.

Reimer PJ, Baillie MGL, Bard E, Bayliss A, Beck JW, Bertrand C. IntCal04 Terrestrial radiocarbon age calibration, 26-0 ka BP. Radiocarbon 2004;46:1029-58.

Remy H. Monographie archéologique. Commune de Vielsalm. Glain et Salm, vol. 14Vielsalm: Haute Ardenne; 1981. p. 44-69. [In French].

Renson V. Apport de la géochimie élémentaire et des isotopes du plomb à l'étude d'un site d'intérêt archéologique situé dans une tourbière des Hautes Fagnes. Master thesis, University of Liège, Belgium, 2005, 52 pp. In French.

Renson V, Fagel N, Nekrassoff S, Streel M, De Vleeschouwer F. Pourquoi une route pavée (via Mansuerisca ?) au travers des tourbières ? Enfin une hypothèse ...qui tient la route. Hautes Fagnes 2005;2005-2:22-4 [In French].

Renson V, De Vleeschouwer F, Fagel N, Mattielli N, Nekrassoff S, Streel M. Early $\mathrm{Pb}-\mathrm{Zn}$ mining and transport revealed by elemental and lead isotopes geochemistry nearby a Late Roman to Merovingian cobbled road (Belgium). A direct application of geochemistry to archaeology. Vienna: European geoscience Union General Assembly; 2007. 15th-20th April.

Rosman KJR, Ly C, Van de Velde K, Boutron CF. A two century record of lead isotopes in high altitude Alpine snow and ice. Earth Planet Sci Lett 2000;176:413-24.

Settle D, Patterson CC. Lead in Albacore: guide to lead pollution in Americans. Science 1980;207:1167-76. 
Shotyk W. The chronology of anthropogenic, atmospheric $\mathrm{Pb}$ deposition recorded by peat cores in three minerogenic peat deposits from Switzerland. Sci Total Environ 2002;292:19-31.

Shotyk W, Goodsite ME, Roos-Barraclough F, Givelet N, Le Roux G, Weiss D, et al. Accumulation rates and predominant atmospheric sources of natural and anthropogenic $\mathrm{Hg}$ and $\mathrm{Pb}$ on the Faroe Islands. Geochimic Cosmochim Acta 2005;69:1-17.

Shotyk W, Goodsite ME, Roos-Barraclough F, Frei R, Heinemeier J, Asmund $\mathrm{G}$, et al. Anthropogenic contributions to atmospheric $\mathrm{Hg}$, $\mathrm{Pb}$ and $\mathrm{As}$ accumulation recorded by peat cores from southern Greenland and Denmark dated using the $14 \mathrm{C}$ "bomb pulse curve". Geochimic Cosmochim Acta 2003;67:3991-4011.

Shotyk W, Weiss D, Kramers JD, Frei R, Cheburkin AK, Gloor M, et al. Geochemistry of the peat bog at Etang de la Gruère, Jura Mountains, Switzerland, and its record of atmospheric $\mathrm{Pb}$ and lithogenic trace metals (Sc, Ti, Y, Zr, and REE) since 12,370 14C yr BP. Geochimic Cosmochim Acta 2000;65:2337-60.

Shotyk W, Weiss D, Appleby PG, Cheburkin AK, Frei R, Gloor M, et al. History of atmospheric lead deposition since 12,370 $14 \mathrm{C}$ yr BP from a peat bog, Jura mountains, Switzerland. Science 1998;281:1635-40.

Shotyk W, Cheburkin AK, Appleby PG, Frankhauser A, Kramers JD. Two thousand years of atmospheric arsenic, antimony, and lead deposition recorded in an ombrotrophic peat profile, Jura Moutains, Switzerland. Earth Planet Sci Lett 1996;145:E1-7.

Sonke JE, Hoogewerff JA, van der Laan SR, Vangronsveld J. A chemical and mineralogical reconstruction of $\mathrm{Zn}$-smelter emissions in the Kempen region (Belgium), based on organic pool sediment cores. Sci Total Environ 2002;292:101-19.

Streel M, Renson V, De Vleeschouwer F. Palynological and geochemical data in peat sediments at the side of an old (Roman to/or Merovingian) paved road in the Hautes-Fagnes. Carnets de Géologie/Notebooks on Geology, Brest, Article 200X/XX (CG200X AXX); 2006.

Stuiver M, Reimer PJ, Reimer RW. CALIB 5.0. [WWW program and documentation], 2005.
Twardowska I, Kyziol J, Goldrath T, Avnimelech Y. Adsorption of zinc onto peat from peatlands of Poland and Izrael. J Geochem Explor 1999;66:387-405.

Véron A, Flament P, Bertho ML, Alleman L, Flegal R, Hamelin B. Isotopic evidence of pollutant lead sources in Northwestern France. Atmos Environ 1999;33:3377-88.

Vile MA, Wieder RK, Novak M. Mobility of $\mathrm{Pb}$ in Sphagnum-derived peat. Biogeochemistry 1999;45:35-52.

von Storch H, Costa-Cabral M, Hagner C, Feser F, Pacyna J, Pacyna E, et al. Four decades of gasoline lead emissions and control policies in Europe: a retrospective assessment. Sci Total Environ 2003;311: $151-76$.

Wastiaux C., Schumacker R. Topographie de surface et de subsurface des zones tourbeuses des réserves naturelles domaniales des Hautes-Fagnes. Convention C60 entre le Ministère de la Région Wallonne, Direction générale des Ressources naturelles et de l'Environnement, et l'Université de Liège. Unpublished report 2003, 52 p.+annexes. In French.

Wedepohl KH, Correns CW, Shaw DM, Turekian KK, Zeman J. Handbook of geochemistry. Springer-Verlag; 1978. p. 22A3-L2. [4].

Weis D, Kieffer B, Maerschalk C, Pretorius W, Barling J. Highprecision $\mathrm{Pb}-\mathrm{Sr}-\mathrm{Nd}-\mathrm{Hf}$ isotopic characterization of USGS BHVO-1 and BHVO-2 reference materials: comparison of first and second generation samples. Geochem Geophys Geosyst 2005;6. doi:10.1029/2004GC000852.

Weiss D, Shotyk W, Kramers JD, Gloor M. Sphagnum mosses as archives of recent and past atmospheric lead deposition in Switzerland. Atmos Environ 1999;33:3751-63.

Weiss D, Shotyk W, Rieley J, Page S, Gloor M, Reese S, et al. The geochemistry of major and selected trace elements in a forested peat bog, Kalimantan, SE Asia, and its implications for past atmospheric dust deposition. Geochimic Cosmochim Acta 2002;66:2307-23.

West S, Charman DJ, Grattan JP, Cheburkin AK. Heavy metals in Holocene peats from South West England: detecting mining impacts and atmospheric pollution. Water Air Soil Pollut 1997;100:343-53. 